\title{
NF2 Gene Mutation
}

National Cancer Institute

\section{Source}

National Cancer Institute. NF2 Gene Mutation. NCI Thesaurus. Code C45669.

A molecular genetic abnormality that refers to the mutation of the NF2 gene located at $22 \mathrm{q} 12.2$. 